\title{
Capitalisms, Generative Projects and the New STS
}

\author{
Kelly Moore \\ Loyola University Chicago, kmoore11@luc.edu
}

Follow this and additional works at: https://ecommons.luc.edu/soc_facpubs

Part of the Sociology Commons

\section{Author Manuscript}

This is a pre-publication author manuscript of the final, published article.

\section{Recommended Citation}

Moore, Kelly. Capitalisms, Generative Projects and the New STS. Science as Culture, , : , 2020. Retrieved from Loyola eCommons, Sociology: Faculty Publications and Other Works, http://dx.doi.org/10.1080/ 09505431.2020 .1841152

This Article is brought to you for free and open access by the Faculty Publications and Other Works by Department at Loyola eCommons. It has been accepted for inclusion in Sociology: Faculty Publications and Other Works by an authorized administrator of Loyola eCommons. For more information, please contact ecommons@luc.edu. c) (†) $\ominus$

This work is licensed under a Creative Commons Attribution-Noncommercial-No Derivative Works 3.0 License. (c) Taylor and Francis, 2020. 


\section{Capitalisms, Generative Projects and the New STS}

Kelly Moore

The 2019 re-founding of Science for the People (SftP), as an organisation and magazine, happened at a moment when new critical science and technology studies (STS) journals were established. In these journals, feminisms, racial formations, queerness, empire, capitalisms, warfare, and environing, among other topics are being formulated in new ways. This new scholarship is being published from settings, journals, and intellectual networks that have developed outside the mainstream of STS. These new journals anchor a heterogeneous, expansive STS that includes new ways of engaging issues that were originally taken up by Science for the People in the 1970s, but were absent from early STS. The absence of critical approaches in mainstream STS emerged from STS' long engagement with liberalism and interactionism. The neoliberal shifts in the goals of contemporary universities reinforced these absences, a point that I develop using my own academic biography, which was shaped by the Science Wars, 9/11, and the exacerbation of profit-making pressures on higher education. However, new STS journals and projects are reengaging capitalisms, reinforcing the importance of positionality/relationality as starting points for scholarship, and placing emphasis on generative projects.

\section{My entry to radical science and to the political economy of science}

Before explaining those shifts, I provide a brief intellectual biography that shapes my interpretations. I was trained as a liberal student of social movements in a mainstream sociology department with no sociology of science, feminist, or critical race studies faculty or courses. I was centrally interested in how people remade political systems. I had no interest in the study of static forms of social life, nor any interest in the individualism that was a central element of sociological analysis. The War against the Vietnamese hurt or killed people in my working class neighborhood of origin. The causes of the Black Power, anti-war and feminist movement projects began to cohere under a racial capitalism framework that I learned about in my high school Advanced Placement history course, taught by the only Black woman teacher I have studied under.
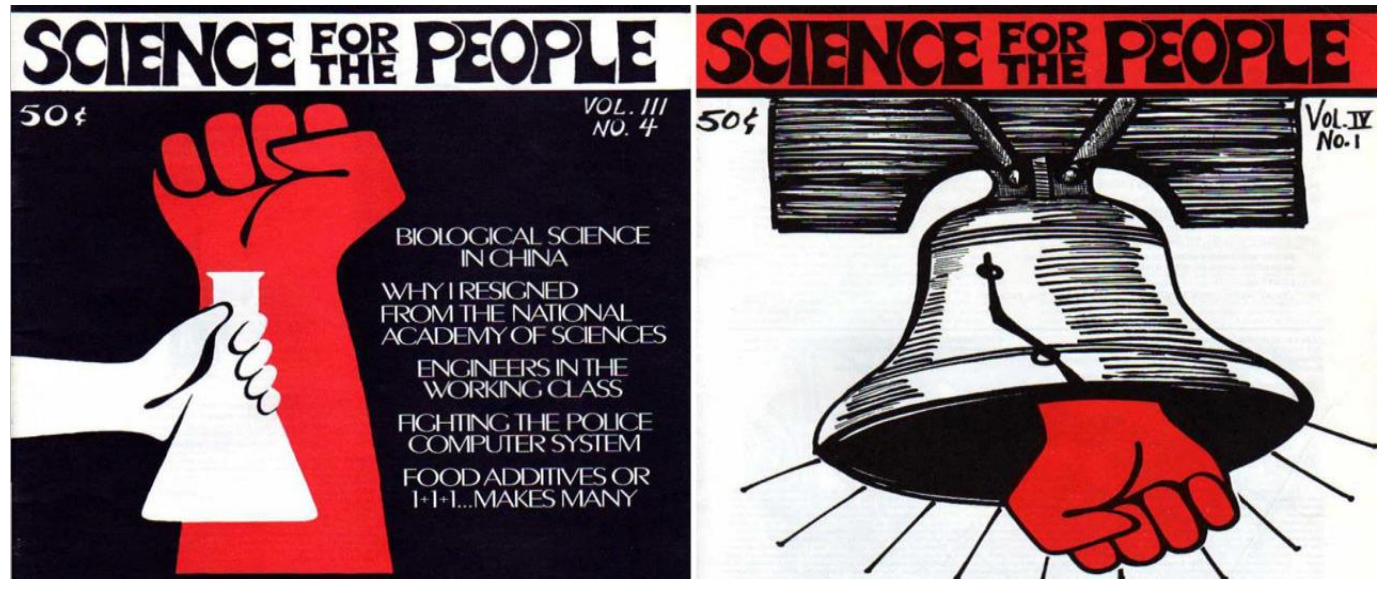

Figure 1: Anti-oppression salute next to a chemical flask; freedom fist and Liberty Bell. Credit: Science for the People Magazine, 1972 and 1973, https://scienceforthepeople.org

My graduate school research interest in science, the military, and politics came out of the trashliterally. A faculty member leaving the department discarded papers, supplies and books in several boxes in the hall, which I dug through to find pens, paper, and books. I found a copy of SftP from 1972. I was 
dumbstruck by what I saw: an Erlenmeyer flask superimposed over a "freedom" fist and "science for the people" emblazoned on the front cover (Figure 1, left side).

Why would scientists, whom I assumed traded on objectivity and depended on the government for money, be objecting to the US war against the Vietnamese and scientists' involvement in making that happen? Who were these "people" science was for? Inside the magazine, that war was described as racist, adding to my own experience with its technological horrors, including the death of my babysitter by a fragment bomb, and the angry or withdrawn Vietnam War veteran fathers who populated my neighborhood and whose troubles were exacerbated by the economic downturn in the early 1970s.

The magazine cover had little to do with the liberal sociology that I had been taught, which insisted that social movements were about a generic class of have-nots challenging the powerful, and that sociological methods to understand them ought to imitate those (supposedly) used by natural and physical scientists. Weren't these scientists anxious about whether people would think of them as objective? I pursued these puzzles and connected them to a longer history of the disruptions of what I called the organizational and moral integrities on which scientists had long traded (Moore 2008).

I left graduate school without the kinds of intellectual backing, networks, and social supports that are the usual stuff of academic success stories, partly because my work did little to extend the empires of some of my advisors. Like others in this position, this experience of being in an edge-world, I hoped, would provide the freedom to make explicit scientists' efforts to consciously create knowledge systems that generate enough for all, less death and suffering, and greater human dignity. The liberal and interactionist contours of STS and the postmodernist challenges that resulted in "science wars" pushed explicit attention to politicized scientists, as well as capitalisms, racisms, and misogynies, into parallel but generative and political intellectual spaces. These parallel worlds have now become the very center of STS.

\section{STS in the '70s and '80s: The Ascent of Postmodernism}

\section{The Disruption of Rationality (in the Lab): the Sociology of Scientific Knowledge}

The central tendencies of STS in the 1970s and the 1980s moved in two directions. The first, best represented in the journal Social Studies of Science (SSS), was toward a question that had traditionally been the purview of philosophers: how did scientists come to decide that claims were proven or factual? The philosophy of science and the natural and physical sciences had long been allied, in the sense that philosophers of science often saw their work as being of assistance to the scientific enterprise. SSS volume 4 (1974), shifted that alliance in an important way. In his study of the TEA Set, Harry Collins ethnographically observed that unspoken, tacit knowledge and the social networks in which people were embedded were the stuff of scientific facts, not clean, neat, logical processes (Collins 1974). Collins' work and that of others who were extending Merton's concept of the norms of science illuminated the linguistic, quotidian, and material practices that went into making scientific claims.

Concepts such as proof and accuracy, this line of work showed, were social agreements that were embedded in social ties and face-to-face activities. The phenomenological and the linguistic, not large-scale institutions, were the necessary starting point for understanding the content of scientific knowledge. Trevor Pinch, Michael Lynch, and John Law were major forces in formulating this school, Lynch via ethnomethodology, Pinch, who worked with Collins, in pursuing the parallels between ordinary and scientific reasoning, and Law by linking science and semiotic performance (Collins 1974; Pinch 1979; Law 1974).

In making these moves, this school, known at first as the Sociology of Scientific Knowledge (SSK), minimized or ignored questions of capitalism, sexism, impoverishment, or why some kinds of people (mostly men, mostly white) and not others were at the scientific bench, and how and why science worked 
better for some groups rather than others. These questions were being addressed (e.g., Rose and Rose 1976; Blume 1974; Haraway 1979), but this work was antithetical to the postmodernist critique of stability, structure, and materiality that was coming to dominate STS. It is unfair though to suggest that SSK had no engagement with the governance of science; authors were often forthright about how their work might help address public technoscientific issues. They made clear that that controversies are not typically settled by facts, and called for an appreciation of what science-as-knowledge could and could not do in systems of scientized, liberal government.

Yet the overarching intellectual project never centered questions about how science was related to racial, gendered, capitalist, and colonialist life, nor did it have much to say about why and how technoscience harmed some groups and life forms, but benefitted others. The lab and the workshop, not the plantation or the Pentagon, were the sites for the social study of science, and attention to language, symbols, and local materiality were the means by which knowledge-making could be known.

Policy, Controversy and The Scientific Field: STHV in the 1970s and 1980s

The SSK approach, still most visible in SSS but also in Science, Technology and Human Values (STHV, was only one way in which STS unfolded separately from the concerns voiced in SftP in the 1970s and 1980s. Its other formulation was more visible in STHV, originally published as a newsletter by Harvard University's History of Science Program, with physicist Gerald Holton and science journalist William A. Blanpied as its editors. Its original focus was on the problem of science communication, and specifically, with concerns about managing public understandings of science, by drawing on a wide range of academic expertise. As they wrote in their original newsletter, “...insight into the attitudes of various key groups must of necessity be interdisciplinary in nature, involving not only scientists but scholars in the social studies and the humanities, as well as thoughtful journalists, essayists, and other responsible critics outside the academic professions" (1972: 2, emphasis mine). Unlike the SSK School or SSS, this project had strong federal backing, supported by a grant from the US National Science Foundation and the Commonwealth Fund. Understanding the social status of science and ensuring that science-as-institution thrived came to be a hallmark of the journal's articles.

By the 1980s, STHV was also publishing a somewhat different form of scholarship: work on "controversies." Dorothy Nelkin, trained as a journalist but making her academic career at Cornell and then New York University's Sociology Department, made an important intervention when she extended her earlier investigations of scientists and the anti-war movement at Massachusetts Institute of Technology, and of opposition to nuclear power, into new ways of conceptualizing controversies. She showed that ignorance and irrationality could not account for controversy, and instead, credited publics with the capacity to know about and rightfully challenge technoscientific problems. Moreover, she situated technology acceptance in ideology (Nelkin 1975; Nelkin and Pollack 1980). Nelkin's and similar works generated more attention to the harms of technologies, which were almost invisible in the SSK school. For Nelkin and others starting with liberal democratic political models, the "problem with science" was the difficulty of squaring popular governance and values with "expert" knowledge, a theme that remains central to liberal STS scholarship today.

While scholarship by women was published in increasing amounts in both journals, feminist scholarship per se, was not, and it was rare that Black, Latinx, Asian, or Indigenous scholars, or topics related to these communities, appeared in SSS or STHV. Intersections between gender, colonialism, racism, and capitalism that were visible-though not central--in SftP were at the edges of STS by the early 2000s, prompting one later observer to ask whether STS was "the place where the Marxist critique of capitalist science goes to die" (Hamlin 2007). Yet as articles in this special issue attest, analyses of science and capitalism - not all of them using strictly Marxist perspectives-were being published elsewhere (Levidow 
(1986), Harding (1983), Kloppenburg (1988), and Kleinman (1995)). Few of the analyses, however, engaged critical race or feminist scholarship, or included those analysts.

\section{Foucault and Knowledge/Power}

Michel Foucault's analysis of knowledge/power, developed in The Order of Things (1966/1970), The History of Sexuality, vol. 1 (1976/1979) and Discipline and Punish (1975/1977) transformed STS. STS analysts began to examine how categories that expressed and built power (e.g., nature/culture, male/female, white/nonwhite, deviant/normal) were made by socially situated experts. Foucault's work reached academic audiences at the same historical moment as vibrant queer and sex positive movements (followed by the devastation of AIDS), Black liberation movements, disability movements, ecological movements and feminist projects around reproduction were transforming academic disciplines, and shaping the formation of new fields with a critical focus, such as Latin American Studies and African American Studies. Orthodox Marxism was no match for these intellectual and political developments, given that its proponents allowed only that economic forces shaped all of social life.

Foucault's work was interpreted in STS in two ways: through the work of Bruno Latour $(1987,1993)$ and his critiques of modernist agency and human/nonhuman divides; and second, through the robust and powerful work of scholars, particularly in the humanities, who traced the formations of the technologies of race, gender, sexuality, disease, and normality via their travels through technologies, broadly speaking, rather to single sources. These approaches also placed scientists and engineers, as historical and presentday actors, in processes of making technoscientific categories that could not be read from capitalist projects alone, and allowed for resistance and domination to coexist.

By the late 1980s, three dominant strands of STS existed--SSK, liberal democratic, and Foucauldian-none of which placed capitalism at its center. By the 1980s, they intersected with a new version of the university: the economic engine, with technoscience as its fuel (Slaughter and Leslie 1997). Profit making was only one face of the new knowledge capitalism. Particularly taking hold in Great Britain, academic researchers were to demonstrate that their work had "relevance," though there were no measures or demands for reforming epistemological systems so that the causes of inequalities were addressed; the measures were about producing measurable outputs in the form of applications (Shore and Wright, 1999). Still, the economic value of knowledge trumped social value (Vallas and Kleinman 2001). As a Biology faculty member at Columbia University succinctly and haughtily told me in 1989, the Sociology Department was now "on welfare." While anti-capitalist STS scholarship was being written in STS and activist projects of the sort that SftP members were engaging, by the late 1980s, mainstream STS and the approach that Science for the People took were operating on decidedly different tracks.

\section{Further Invisibilizing the Science-Capital War Nexus: University Ghosts, The Sokal Affair, and 9/11}

Channeling knowledge, as every STS scholar recognizes, occurs in many ways across varied scales. In this regard, I turn to a smaller scale, revisiting my own experience in attempting to write an STS interpretation of the importance of Science for the People, at Columbia University in New York City in the 1990s. During 1993-2003 I was researching and writing, Disrupting Science (Moore, 2008) while an Assistant Professor at Barnard College, the women's college affiliated with Columbia University. The aim of the book was to challenge the myth, as pervasive in STS as in popular accounts, of scientists as apolitical, and to show the varied ways that they had challenged the capture of science by military capitalism in the USA during the Cold War. There were still ghosts (Subramaniam 2014) of Columbia's military, technoscientific colonialist projects (e.g., the development of weapons to use in the War against the Vietnamese) and the university received considerable levels of military funding. 
Colombia's "60s narrative" had long been that student and off-campus Black political groups occupied buildings to protest the plan to build a gym in Morningside Park and Columbia's military ties; Columbia acceded to the first demand, and cut its ties with the Institute for Defense Analysis (IDA). A new official history of the university was underway, written by Barnard historian Robert A. McCaughey, whose

analysis of those events featured attention to student-police interactions and close study of the protests, but not the issues themselves (McCaughey 1999). My archival research at the institution revealed that students had been protesting against the military science research for years before 1968 occupation of the university and that faculty themselves were also involved in these activities. Yet I was warned that the official history would not emphasize that, since the focus of events on that campus in 1968 was to be the gym that was never built. Contradicting that, they suggested, would be unwise. If I were to proceed with my project, a colleague warned me, I would not be looked upon favorably by faculty who would be judging my promotion case. Another told me that “Even the National Endowment for the Humanities doesn't fund anything on the war [against the Vietnamese]: does that tell you anything? Find another subject."

The situation grew more intense. A graduate student at another university was writing a dissertation about the history of Science for the People. Yet the background from which he came-active militaryseemed an unlikely pathway to the study of radical scientists. He produced interviews and other important archival materials on and from the group, however. Yet in one of our few conversations, he was centrally concerned with whether I had found evidence that the "Unabomber" (Ted Kaczinskl) had been member of Science for the People. Against the backdrop of the hostility toward the project I experienced at Columbia, that a scholar with ties to the military was enthusiastically involved in studying Science for the People, and querying me about the Unabomber the group's potential ties to violence, suggested that there might be greater political stakes in my analysis than problems with tenure.

In 1995, Alan Sokal, a physicist and self-described scientific realist, submitted a deliberately disingenuous article to the New York University-based Social Text, a journal that published postmodernist scholarship, without peer-review (Sokal, 1996). He hoped to confirm the hypotheses put forth by other scholars that humanities journals would publish anything with a leftist bent. His gleeful exposure of his hoax was the talk of the humanities in New York. In my own academic life, my insistence that what I was writing was not postmodernist and nor was Science for the People, fell on deaf ears. Sokal's hoax had diverse responses - variously praised or feared. My suggestion that Sokal's realist fundamentalism and malicious intent ought instead to be a subject of critical discussion met outright hostility from many social scientists at the university, as well as natural and physical scientists. A sympathetic reading of an anticapitalist analysis of science--by scientists--seemed to invite the sort of ridicule that the editor of Social Text subsequently endured.

After a spring leave, I was ready to complete the manuscript in 2001. But the events of September 11,2001 changed that calculus. New York's police had already been using a wide range of military weapons, but now after the attacks, there were soldiers on the streets in full uniform carrying weapons, the sky was filled with military planes shrieking across the sky, and smoke streamed eastward across the tip of Manhattan. They prompted responses among New York's residents and leaders that reinforced what I was trying to write about. Within hours of the attacks, Mayor Giuliani and Governor Pataki held a press conference, in which Pataki focused his remarks on the people of New York and their sufferings and capacities for rebuilding. Giuliani, on the other hand, quickly moved past the people that Pataki had emphasized, and on to business: "We have the strongest business community, and we are going to call on them, we are going to need their help..." (Giuliani 2002). Barnard President Judith Shapiro sent a message to the college, telling us that the university had arranged a bus to take us to downtown stores, where, by shopping, we could contribute to the city's recovery.

The 9/11 attacks were exploited to intensify support for highly technologized military defenses of capitalism. As the identities of the attackers were made visible, talk among faculty whom I had initially trusted turned to enthusiasm for a military response against Osama bin Laden; Operation Enduring 
Freedom-the country's first major military foray into Afghanistan-began shortly afterward. I knew of just a few people who, like me, did not want to "hunt down" the leaders of the attack; for the rest, this hunting was not only fait accompli, but something to relish. How high tech war produced capital unfolded in other ways, too. The city dealt with its grief through nearly grotesque levels of material donations to firefighters; by 2012, they were begging people to stop sending things (Bovino 2012).

The existence of militarized capitalism was no longer invisible-it was embraced, and the racialization of the new enemy - the Muslim - had taken hold. I tried to make sense of these events and the discouragement I experienced in my efforts to write about Science for the People and its anti-capitalist focus. I read it as a continuation of the very issue that generated Science for the People in the first place: the colonialist War against the Vietnamese. Science for the People seemed to be more relevant than ever before, yet the denials of militarized capitalism at the university, the collapsing of post-modernism and historical analysis of specific anti-military events, and then the deep and very local embrace of high-tech warfare after attacks, pointed toward never finishing the project.

I did not get tenure at that institution. As always, there are complex reasons, not least of which is that I was unable to finish the book, perhaps for reasons that might be obvious. I was also in good (female) company: at that time at Barnard, about $22 \%$ of the women who came up for promotion were indeed promoted; the rate was $50 \%$ for men, and higher if they had a doctorate from Columbia. I interject my biography here to shed light on another way that power/knowledge operates to channel ways of thinking and imagining, which complements the institutionalist/origins stories in STS and their intersection with the university as economic engine. The intersection of capitalism, militarism, and technoscience was ever present, yet invisible in mainstream discourse, at least if the halls of Columbia University and the pages of STS journals are any measure.

\section{New STS: Finding Capitalisms that were Never Lost in Science for the People}

In 2019 the magazine Science for the People (SftP) was re-founded, with a specific call for papers from scientists, engineers, and STS scholars. As a result, intellectual networks that were developing and thriving away from the centers of STS, and indeed, perhaps have thrived because they were not being "disciplined" through mainstream STS, are now remaking STS in important ways. Of these journals, only one, the new SftP, is a journal for natural and physical scientists (and STS scholars, who might also be scientists) to present critical political analysis and supporting evidence and theory. STS has long treated scientists as if it were rare for scientists to engage in public politics that is critical of the ideal of neutral science and the neutral scientist.

That scientists can be sophisticated analysts of the social and political origins of research projects, scientific practices and applications, and act in ways to encourage human thriving is increasingly understood by STS scholars, and thus, SftP deserves to be understood as means by which scientists are being refigured as political actors in STS. This Forum is one move in that direction. There is also reason to consider that intersectional anti-capitalist scientific projects are a challenge to mainstream STS, and what might need to happen to further strengthen the connections between Science for the People and its magazine, and the new STS.

The New STS, which includes the revival of Science for the People, understands capitalist formations in relation to indigeneity, race, gender, racegender, coloniality, agriculture, war, and technologies of communication and surveillance. Capitalisms and technoscience are now more commonly analytically bound together with other concerns that deepen understandings of how exploitation for profit operates. A second distinguishing feature of new approaches to STS is that some challenge the scientistic stance of a view-from-nowhere (which I also adopted in my earlier work). There is greater insistence on and possibilities for multiple views of technoscience, from situated people who can and sometimes do express hopes, dreams, and pathways for more just technoscientific worlds. Work that is appearing in new STS 
journals frequently refuses the starting points of western, masculinist technoscientific methods and thought, and some of the very questions and concerns that have animated the center of STS for decades.

This way of engaging technoscience has historical roots in a wide range of fields. Orlando Fals Borda (1973) examined participatory action research that began with the knowledge of ordinary people, not modernist capitalist reformers; feminist projects, such as the brilliant analysis of sexist and racist university life in How Harvard Rules Women (New University Conference, 1970), Dorothy Robert's (1997) analysis of the ways that contemporary medicine was organized to ensure that black life did not occur; and Frantz Fanon's analyses of the psychic toll of colonialist racial categories are but a few of these roots.

\section{Re-engagements with political economy}

The buying and selling (and remaking) of the biological is unquestionably the major way in which STS has reengaged political economy. Kaushik Sunder Rajan's Biocapital: The Constitution of Post-Genomic Life (2006), for example, introduced the idea of "technoscientific capitalism," marrying Foucauldian analysis with Marxian approaches, to capture how bio-value was made in the pharmaceutical industry. Sunder Rajan's work made visible the way that markets and the biological were co-produced across India and the US, disrupting and redirecting analyses of domination from the West that had characterized so much of the work of Marxist scholars of science, including those who published in SftP. Similarly, Kimberley Tallbear traced the making of indigeneity through for-profit DNA testing, and how the promise of telling stories of certain kinship reproduced older racist viewpoints (2007), and Shobita Parthasarathy's (2017) scholarship has illustrated how patenting life forms has emerged and its ethical consequences. See also collections of such critical perspectives (Frickel and Moore 2006; Kleinman and Moore, 2014; Pellizzoni and Ylönen, 2012).

\section{Positionality/Relationality Front and Center}

The majority of the writers in SftP magazine were explicit about their normative goals and their political positions, a stance that was, as I suggested earlier, nearly absent in mainstream STS work. However, in new STS journals, making explicit the sources and travels of STS knowledge is central. For the journal Tapuya: Latin American Science, Technology and Society (TLASTS), the founders write that their goal is to: "increase the complexity of the STS scholarly landscape by pushing conventional STS boundaries to include issues, perspectives and methods relevant to Latin America... Tapuya seeks to explore not only the diversity and richness of Latin American STS issues, perspectives and research methods and evidence of the many creative flows of influence that exist between Latin America, Euro-American cultures, and other peripheries, but also resources for STS periphery studies." Not insisting on regional centers, as the older versions of STS that took for granted its Euro-US centrism did, there is also attention to peripheries (Williams, 2020; Williams and Moore, 2019).

Similarly, Catalyst aims to broaden engagements with topics that had not been centered in STS, but which have been in the networks of feminist studies. From their statement of purpose:

Catalyst publishes...feminist STS scholarship that reroutes the gendered, queer, raced, colonial, militarized, and political economic beings and doings of technoscience. Its mission is to support innovation in feminist STS and related areas of study, as well as to provide a venue for the publishing of activist feminist and critical theory concerning matters of science, technology, information, medicine, media, and more.

And from the journal East Asian Science, Technology and Society: An International Journal (EASTS): “EASTS serves as a gathering place to facilitate the growing efforts of STS networks from Northeast Asia, Southeast Asia, North America, and Europe to foster an internationally open and inclusive community."

These positions and work in the journals themselves mirror some of the older writings in $S f t P$, such as projects and analyses of Latin American agriculture, capitalism, and technoscience, and certainly the situatedness with which feminists in Science for the People began their work. 
Attention to the authors' position relative to their scholarship is also being developed as a methodological intervention, placing the knowers into self-conscious power, emotional and other kinds of engagements with their subjects. The welcome disturbances to older methods (survey, traditional histories, older forms of ethnography, interviewing, and participant observation) generate new ways of representing and circulating knowledge, including the use of creative arts. Parvin (2018), for example, uses his experience in engaging with and circulating digital stories to reject the ways that they are normally understood: as mobile and static, easily turned into data. He insists that listening, not just collecting and analyzing, be brought back into digital story analysis. In doing so, he challenges the Digital Humanities projects that amass enormous amounts of material that is literally dis-placed:

Far from being ready-made commodities of exchange, stories are made and remade in the very particular and fleeting moments of encounter. And so doing justice to stories at least entails acknowledging and embracing the vulnerability, fragility, and uncertainty that permeate the whole, and attending to the act of listening (perhaps even more so than that of collecting and archiving made possible with digital technologies).

\section{Generative Projects vs. Extractive Scholarship}

I close with an extension of the idea that positionality matters, by drawing explicit attention to what we call "generative STS" (Moore and Hernández Vidal, 2020; see also Eglash, 2020 for a related concept). Generative STS is meant to capture collective activities in which participants aim to remake the bios and social life, broadly speaking, in ways that produce vitality and life. When Science for the People member Richard Lewontin explained his decision not to accept membership in the National Academy of Sciences, he argued that he was doing so to draw attention to careerism, or "thinking of yourself as the product" and "looking the other way" (Lewontin, 1991). Lewontin and others in Science for the People, such as John Vandermeer (2020) who has longstanding engagement with communities in Latin America to co-create forms of agro-ecology, placed generative science at the forefront of what they did, rather than relying only on critique, or inventing knowledge that others would take up to pursue justice.

Generative science and STS encompass a wide range of actors, and have (albeit modernist) orientations toward temporality, such that they engage pasts, presents, and remade futurities. Finally, 'generative' refers to projects that refuse to erase histories of suffering and joy. Extractive projects, by contrast, are those by which the stories of other beings and the earth (rocks, fire, air included!) are processed for the consumption of other researchers and career advancement. STS has had a long history of "engaged scholarship," encompassing policy advice and strategies for influence (e.g., Parasarathy 2020), participatory design (e.g., Ottinger 2020), and critical data collection and analysis, such as Max Liboiron's (2020) Civic Laboratory for Environmental Action Research. Through the generative form of such interwoven projects, STS scholars are learning and creating for and with non-academics in ways that highlight the many kinds of epistemologies, technologies, and labor that make up technoscience, and contribute to its reorganization in ways that are explicitly integrating larger-scale political arrangements. Moreover, they refuse the older sometimes overly determinative stories of domination/subjugation that sometimes overwhelmed the scholarship in the publications of Science for the People.

Many more examples could be given, for this sort of work is now nearly commonplace. Some universities place pressure on faculty to "serve the community" for multiple purposes. "Service" logic is not what I mean by 'generative' work. This form of scholarship cannot and should not displace theory, nor ways of working that do not have immediate "applications" and cannot be considered "innovations."

The intellectual world of STS is richer beyond what I ever could have imagined in the mid-1990s. As STS has long recognized, domination always generates resistance. Thus, generative work has always been carried out by scientists, engineers, and STS scholars. The revival of SftP in particular gives voice to the organized, active, practices of scientists' challenges to domination, and their efforts to toward justice. Across the new STS journals, particularly in work by feminists, central are questions of care, a word that hardly appeared in the old SftP, but was surely the antithesis of the capitalist-based destructions that they 
emphasized. The new SftP and the New STS, led by scholars historically marginalized in the academy, are providing a vibrancy that moves the field to places and subjects not beholden to the styles of feeling, thought, and practice from which STS originally emerged. Beyond "prefiguring" new worlds, they are making them right now.

Acknowledgements: Many thanks to Savina Balasubramanian, Nathalia Hernández Vidal, Les Levidow, Peter Taylor, Sigrid Schmalzer and Rhys H. Williams for their comments.

\section{References}

Blume, S. (1974). Toward a Political Sociology of Science. (New York: The Free Press).

Bovino, A. (2002). You're Too Kind, Firefighters Say; Gifts Pour in but Space for Them is Scarce, New York Times July 24, p. B1.

Collins, H. (1974). The TEA Set: Tactic Knowledge and Scientific Networks. Social Studies of Science, 4, pp. 165-186.

Eglash, R. (2020) Generative Justice https://generativejustice.org/ Accessed March 15, 2020.

Fals Borda, O. (1973). Reflexiones Sobre la Aplicación del Método de Estudio-Acción en Colombia (Asunción: Centro Paraguayo de Estudios Sociológicos).

Frickel, S. and Moore, K. eds (2006). The New Political Sociology of Science: Institutions, Networks and Power (Madison, Wisc.: University of Wisconsin Press).

Foucault, M. (1966/1970). The Order of Things: An Archaeology of the Human Sciences (New York: Pantheon). . (1975/1977). Discipline and Punish: The Birth of the Prison (New York: Random House). . (1976/1979). The History of Sexuality, vol. 1 (London: Allen Lane).

Giuliani, R. (2002). https://www.youtube.com/watch?v=xiA5NNjf7XQ

McCaughey, R. A. 1999. Columbia '68: A Near Thing."

https://web.archive.org/web/20061006053845/http://beatl.barnard.columbia.edu/cuhistory/archives/colu mbia68/McCaughey.htm 
Moore, K. (2008). Disrupting Science: Social Movements, Scientists, and the Politics of the Military 19451975 (Princeton: Princeton University Press).

and N. Hernández Vidal (Forthcoming, 2020). Generative Dissent in/around Technoscience, Engaging STS, Special Issue on Dissent.

Nelkin, D. (1975). Jetport: The Boston Airport Controversy (Piscataway, NJ: Transaction Publishers).

and M. Pollack (1980). Ideology as Strategy: The Discourse of the Anti-Nuclear Movement in France and Germany. Science, Technology and Human Values, 5 (30), pp. 3-13.

New University Conference. (1970). How Harvard Rules Women (New University Conference). Available at http://bcrw.barnard.edu/archive/education/How Harvard Rules Women.pdf

Ottinger, G. (2020). https://www.fairtechcollective.org/ Accessed March 15, 2020.

Parthasarathy, S. (2019). Science and Policy Engagement http://shobitap.org/activities Accessed March 15, 2020.

. (2017). Patent Politics: Life Forms, Markets and the Public Interest in the United States and Europe (Chicago: University of Chicago Press).

Parvin, N. (2018). Doing Justice to Stories: On Ethics and Politics of StoryTelling. Engaging STS 4. https://estsjournal.org/index.php/ests/article/view/248.

Pellizzoni, L. \& Ylönen, M. eds (2012). Neoliberalism and Technoscience: Critical Assessments. (Farnham, Surrey: Ashgate Publishers).

Pinch, T. (1979). Normal Explanations of the Paranormal: The Demarcation Problem and Fraud in Parapsychology. Social Studies of Science 9: 329-48.

Roberts, D. (1997). Killing the Black Body: Race, Reproduction and the Meaning of Liberty (New York: Vintage).

Rose, S. and H. Rose eds (1976). The Political Economy of Science: Ideology In/Of the Natural Sciences (London and New York: MacMillan). 
Schmalzer, S., D. S. Chard, and A. Botelo (Eds) (2018). Science for the People: Documents From America's Movement of Radical Scientists (Amherst: University of Massachusetts Press).

Slaughter, S. and L.L. Leslie. (1997). Academic Capitalism and the New Economy: Markets, State, and Higher Education (Baltimore: The Johns Hopkins University Press).

Shore, C. and S. Wright (1999). Audit Culture and Anthropology: Neoliberalism in British Higher Education, The Journal of the Royal Anthropological Institute, 5(4), pp. 570-575.

Sokal, A. D. (1996). Transgressing the Boundaries: Toward a Transformative Hermeneutics of Quantum Gravity, Social Text, 46-47, pp. 217-252.

Subramaniam, B. (2014). Ghost Stories for Darwin: The Science of Variation and the Politics of Diversity (Urbana: University of Illinois Press).

Sunder Rajan, K. (2006). Biocapital: The Constitution of Post-Genomic Life (Durham: Duke University Press).

Tallbear, K. (2007). Narratives of Race and Indigeneity in the Genographic Project, Journal of Law, Medicine \& Ethics, 35(3), pp. 412-424.

Vallas, S. and D. L. Kleinman. (2001). Science, Capitalism and the Rise of the 'Knowledge Worker': The Changing Structure of Scientific Knowledge Production, Theory and Society 30, pp. 451-492.

Vandermeer, J. (2020). https://Isa.umich.edu/eeb/people/faculty/jvander.html

Accessed March 15, 2020.

Williams, L. (2020). Knowledge from the Margins. https://www.knowledgefromthemargins.org/ Accessed March 15, 2020.

Williams, L. and Moore, S. eds (2019). Justice and Counter-Expertise, Science as Culture, 28(3): pp. 251-401 https://www.tandfonline.com/toc/csac20/28/3?nav=tocList. 